www.czasopisma.marszalek.com.pl/pl/10-15804/npw

\author{
Katarzyna Michalewicz \\ Uniwersytet Wrocławski \\ ORCID: https://orcid.org/0000-0002-1011-906X
}

\title{
The image of Chinese and Japanese Theatre in selected popular and artistic press printed in Poland in 1930s
}

\section{The image of Chinese and Japanese Theatre in selected popular and artistic press printed in Poland in 1930s.}

\section{Abstract}

Journalists who described Oriental theatres usually based their narrative on personal experience. Both specialist, mass and popular press paid particular attention to elements that distinguished Japanese and Chinese theatre from their European counterpart. The length of performance, innovative technical solutions, different acting style were the elements that received most attention. Nonetheless, sometimes it was impossible to explain the origins of those differences.

Furthermore, the above-mentioned differences usually spoke against Chinese theatre. It was criticized for different music, moveable stage scenery, exaggerated acting that was hard to understand. Such attitude was the result of lack of understanding of Chinese opera's conventions. On the other hand, press eagerly commended the richness of Chinese actors' costumes and „,shadow puppet theatre”. Moreover, Polish press also stressed that both classical and modern Chinese theatre enjoyed immense popularity among Chinese people.

Polish press went easy on theatrical art in Japan depicting differences that were in many cases the same as in Chinese theatre as something neutral, even positive as it gave the play magical touch. Sometimes it was emphasized that Japanese theatre could become a source of inspiration for its European counterpart. It was praised for masks, costumes, 
moveable stage scenery and music. It is interesting that in the last two instances Chinese theatre was looked down on. Polish press also spoke favourably of puppet theatre and „Takarazuka” performances. On the other hand, magazines' opinions on acting varied.

Keywords: The Second Polish Republic, the interwar polish press, The Japan, The China, theatre, Chinese opera, acting

\section{Образ китайского и японского театров в избранной популярной и художественной прессе Польши 1930-х годов}

\section{Аннотачия}

При описании дальневосточного театра журналисты обычно использовали собственный опыт. И специализированная, и массовая, и популярная пресса уделяла особое внимание тем элементам, которые отличали китайский и японский театр от его европейского аналога. Среди них в основном были отмечены: длительность спектакля, новаторские технические решения, а также иная игра актеров. Однако не всегда можно было объяснить причины различий.

Более того, в случае китайского театра вышеупомянутые различия обычно трактовались в невыгодном свете. Его критиковали, в частности, за другую музыку, трогательные декорации, а также преувеличенную и при этом непонятную игру актеров. Такое мнение сложилось из-за неправильного понимания китайской оперной конвенции. С другой стороны, пресса высоко оценила богатство костюмов китайских актеров, а также «театр теней» и подчеркнула, что как традиционный, так и современный китайский театр был популярен среди жителей Поднебесной.

Журналы оценивали театральную постановку в Стране восходящего солнца гораздо мягче, показывая различия, часто такие же, как в китайском театре, как нечто нейтральное и даже положительное, придающее пьесе определенную магию. В то же время иногда подчеркивалось, что японский театр может стать источником вдохновения для своего европейского аналога. Его хвалили в первую очередь за: маски, костюмы, а также за движущиеся декорации и музыку. Стоит добавить, что в последних двух случаях виноват китайский театр. Положительно отзывались и о кукольном театре, и о спектаклях «Такаразуки». С другой стороны, журналы по-разному оценивали актерское мастерство.

Ключевье слова: Вторая Польская Республика, довоенная пресса, Япония, Китай, театр, китайская опера, актерское искусство 
The aim of the article is to try to discuss how the Polish press described 1 Chinese and Japanese theater in the 30s of the twentieth century. At the same time, I would like to pay special attention to how the magazines assessed the differences between the theatre from the Middle Kingdom and the Land of the Rising Sun and European theatre, as well as what knowledge the journalists had on this subject.

In my research work, I chose several periodicals that are re-operative for this period, both the most popular and specialized, devoted to art and culture. Among them were: published by the most popular and opinion-forming press concern Ilustrowany Kurier Codzienny [The Illustrated Daily Courier]: a sensational monthly magazine "As" [Ace], highly popular illustrated weekly magazine "Na Szerokim Świecie", and Warsovian radio weekly "Antena" [Antenna]. It is worth noting that in the years 1929-1933 the total circulation of IKC was about 180,000 on Sunday, and the company's income in 1930 amounted to about PLN 700,000 at that time. In the query I also included: a popular travel - geographic magazine published in Lviv "Z Bliska i z Daleka" [From Near and Far] and a woman's magazine, which was dedicated to citizeness from upper-class: "Bluszcz" [Ivy]. The third group of primary sources was: the specialist press such as: "Teatr" [Theatre], "Teatr w Szkole" [Theatre at school] and "Życie Sztuki" [Life of Art], which also paid an attention to Far Eastern theatre (Paczkowski, 1980, p. 107-108, 164-165, 248-249 and 278).

Both Japanese and Chinese cultures, so different from European, never failed to fascinate the citizens of the Second Polish Republic. As a trivia, it can be added that already in 1902, in Warsaw, Krakow and Lviv performed: Sado Yakko (1871-1946) a professional actress, dancer and actor and comedian Kawakami Otojirō (1864-1911). Their visit to these cities was part of their, more than a year-long tour of Europe. Their performances were also widely echoed in the Polish press, and the figure and work of Sada Yakko became an inspiration for the artists of Young Poland. Also, the Polish press printed in the 1930s tried to introduce the readers to matters related to the cultural heritage of Far East, including theatre.

It was not without significance that in 1930s Polish theatrical contacts with the Far East were intense. In 1935, Polish press, especially daily papers, widely commented on a three-day-stay of Mei Lanfang, one of the 
most famous Chinese actors, promoters and reformators of Beijing Opera. Zbigniew Osiński stressed that although the articles dedicated to this event usually had an informative character, they also focused on exotic and sensational character of this event (Osiński, 2008, pp. 49-50). The two-week visit of the kabuki theatre troupe who staged 18 performances in Warsaw, Poznań, Lodz, Cracow, Lviv in 1931 received a great deal of attention. The performance of the theatre troupe called Takarazuka also enjoyed popularity. Both events, vital for Polish cultural contacts with the Orient, influenced press' growing interest in Japanese theatre (Osiński, 2008, pp. 124-127, 147).

A brief mention of Chinese theatre in the pages of "Na Szerokim Świecie" [Around the World] was published by Stanisław Bożałł. He noted that the theater in Shanghai was composed of over a dozen halls and resembled more of an amusement park, located within the walls. He added that he participated in a performance telling the old Chinese story of a princess and robbers, and then a tragedy from the European repertoire ( $W z d t u \dot{z}$ chińskieog muru, 1931, pp. 9). The article of Edward Kuryło published in the specialist magazine "Teatr" [Theatre] provided much more information on Chinese theatre. According to the journalist, the pure form of Chinese theatre could only be seen in the province. However, he warned that this form of art may not be able to cater to European tastes. The correspondent based on his personal experiences of his stay in traditional theatre in Ipoh complained about dirty and stuffy rooms, too brightly lit and too highly positioned scenes. Acoustics and buzzing insects did not make it easier to follow the performance. Kuryło also complained about scarcity of scenic decorations, unprofessional behavior of the scenographer who disturbed actors by changing the scenography during the performance. The play itself also left a lot to desire as it was only composed of monologues and songs full of pathos. Furthermore, the play lacked passion and emotions which made it seem grotesque. The correspondent praised only the rich and colourful costumes (Kuryło, 1931, pp. 192-194). The above-mentioned remarks of Edward Kuryło were correct, but his negative opinion had a lot to do with lack of understanding the dissimilarity between Chinese opera and European theatre. The Chinese opera is based on a convention. As a result, the text is overdramatically recited, actor's movements seem unnatural and decorations are kept to a minimum. Furthermore, acting art includes many canons actors 
have to adhere to if the performance is to be understandable. Therefore, individual characteristic gestures such as shaking hands above your head are ascribed to only one character trait. In comparison with the European scene, the Chinese thrust stage is open to the audience from three sides. Moreover, scenography is often moveable which adds life to a performance. This could explain scenography changes seen by the audience. On the other hand, Edward Kuryło had a point claiming that an authentic Chinese theatre can be seen in the province. Even today plays are performed in classical Chinese or in a local dialect. In the case of plays performed in a local dialect, it is often the only medium in which you can hear language used by the local people. (Künstler, 2019, p. 283; Kajdański, 2005, p. 176). From the description of Edward Kuryło, it appears that he could have witnessed a performance prepared by dixi, i.e. "local theater" or "theater of the earth". It is a variety of theater specializing in staging military plays. It has no scene in our word's sense. Performances usually take place on a small square in the middle of the village or in front of the temple. And the actors are surrounded by spectators on four sides. The set design is symbolic, and the single props are to help the viewer recreate the imaginary world (Łabędzka, 1995, p. 101).

"Na Szerokim Świecie" [Worldwide] praised costumes and actresses' make-up in its description of Chinese theatre. As the title explained, a special hairstyle made of strands of hair covered in a transparent glue where some strands are styled in rings resembling curls is an indispensable addition to a female's mask in Chinese theatre. The weekly newspaper put an emphasis on the fact that such hairstyles required special skills. "Na Szerokim Świecie" [Worldwide] also explained that costumes and ornaments inform character's social and material status, their marital status and even their personality traits (Chińskie maski, 1938, p.9). It is true that masks painted on actors' faces and lavish costumes based on centuries-old conventions have their meaning. They inform about status, gender, personality and the part a character plays in a performance. Both costumes and headdresses modelled after clothes and headdresses worn in Ming Dynasty (1368-1644) no matter when the action takes place (Künstler, 2019, p. 283; Mackerras, 2009, p. 1653). In “Teatr” [Theatre] Edward Kuryło enumerated the elements that distinguished Chinese theatre from European theatre. Chinese theatre did not use curtains, so the audience was able to see what was happening during breaks behind the stage 
and in the changing rooms, men playing women. Performances could last several hours. The correspondent gave an example performance in Shanghai theatre that began in the early afternoon and lasted till midnight. However, he added that Shanghai theatre also staged historical plays that lasted many weeks (Kuryło, 1931, pp. 192-194). Magdalena Lipkowska, the correspondent of "Tęcza” [Rainbow], also paid attention to performances lasting even 72 hours, the stage not having a curtain, decorations being changed during the performance, actors playing a few totally different roles, beginner artists being required to learn by heart 360 plays. She also mentioned different music that she considered to be very noisy. The journalist did not like in particular the sound of erhu which she called "a torture" (Lipkowska, 1937, p. 55). "Na Szerokim Świecie" [Worldwide] added that contrary to European theatres, Chinese theatre has recently allowed women to perform. The weekly newspaper also provided a tidbit of information of Yang Zhu Jin (Chinskie maski, 1938, p. 9) being one of the first actresses.

It is true that a performance of Chinese opera can last several hours. Therefore, even today tickets can be bought for the following three days and the performance can be watched in parts. It is also a family entertainment and going for a walk during the performance, shopping at the theatre's canteen and snacking during the performance is nothing to be ashamed of. Also even today, in many varieties of Chinese opera only men are allowed to perform (Künstler, 2019, p. 283). Those customs are the product of performances forming a part of celebrating local festivals and being originally a way of paying homage to deities Thus, people were an additional audience gathering around the stage set up near the temple (Mackerras, 2009, p. 1658). It is worth mentioning at this point that opera or Chinese theatre, unlike European theatre, combines various arts such as theatre, dance, singing, music, acrobatics, martial arts, masks, established make-up, facial expressions. There is also a special canon of stories that every Chinese person knows. "Tęcza” [Rainbow] might have alluded to this fact when it mentioned the requirement of having learnt by heart 360 plays. (Capdeville-Zeng, 2009, s. 172-173).

"Życie Sztuki" [Life of Art] also mentioned the development of modern Chinese theatre: huaju. It is characterized by the lack of music, presenting Western arts and Proletarian influences. Countryside theatre originated from huaju. Nanjing, Hankou, Guangzhou, Beijing, Tianjin, Shanghai were 
cities where flourished modern Chinese theatre. “Życie Sztuki” [Life of Art] considered Tian Han (1898-1968) - "the playwright of South China" and the author of a few works in English to be one of the most important representatives of modern Chinese theatre. This magazine stressed that the current political situation also influenced the development of Chinese theatre. Theatrical works of that period focused on patriotic and social matters such as contraband smuggled by Japanese and Koreans. They were often staged by amateurs: mostly clerks, students and soldiers who formed amateur groups among which The Group of Wartime actors (Hovo-Joei, 1939, p. 256-258) gained the biggest popularity.

It is worth to note, that, Tian Han's modern theatre was supposed to be a "poor theatre" that would abandon the ceremonial convention. In traditional Chinese opera, usually the most experienced actors were also directors, scene designers. Tian Han decided that to be able to revolutionize the theater, he had to entrust these roles to people outside the theater. Thanks to this, avant-garde solutions could appear in art (Kasarełło, 1995, p. 73).

The year 1907 was considered to be the beginning of modern Chinese theatre as a group of students established the theatrical association "Chunliushe" (Spring Willow Society). After the May Fourth Movement from 1919 there was a shift to a spoken theatre huaju mentioned by "Życie Sztuki" [Life of Art]. This magazine emphasized that staged plays most often brought up current topics and patriotic plays about the Anti-Japanese War (Kajdański, 2009, p. 273).

The press stressed that both traditional and modern Chinese theatre enjoyed immense popularity among the Chinese. Edward Kuryło emphasized that Chinese theatres were filled to the brim with audiences, Both the rich and coolies enjoyed watching plays (Kuryło, 1931, pp. 192-194)."Życie Sztuki” [Life of Art] also confirmed that despite traditional Chinese theatre being ossified it still had many enthusiasts. Nonetheless, traditional Chinese theatre was no match for modern art which "bloomed like a noble flower of young Chinese thought and its form encompassed all aspects of Chinese life" (...) "is the blood and the heart of the contemporary generation". The magazine contended that modern Chinese theatre depicted life drama of an individual and society, admonished, called for change, shocked with its message and truth. Therefore, it contributed to the development of free and 
patriotic China (Hovo-Joei, 1939, p. 258). „Bluszcz” [Ivy] on the other hand stated that despite defeats and Manchurian War, Chinese still listened to theatrical plays particularly [Western] plays which were a novelty for them (Carmen, 1931, p. 15). "Życie Sztuki” [Life of Art] added that musical theatres and children's theatres where war orphans performed (Hovo-Joei, 1939, pp. 256-258) enjoyed immense popularity. Here it should be emphasized that Chinese opera especially their local varieties (there were around 330 varieties) had sometimes gone hand in hand with social life and influenced it immensely. But usually it's described in ancient times, where the main protagonists were members of the upper-class. So, it was more focused on universal problems, not this characteristic for modern society.

But in the other side, it is worth to note, that, Tian Han tried to reach the poorest inhabitants of Shanghai. Therefore, his huaju theater tried to imitate reality, it did not require from the participants deep reflection or knowledge of the stage language. The play touched on contemporary problems that the inhabitants of the metropolis had to deal with. Unfortunately, however, his art found little listening to poor Shanghainese, who preferred traditional Chinese opera to his art. The playwright, however, found a common appreciation among the youth and students (Kasarełło, 1995, pp. 79-80).

Therefore, the state always controlled it and used it for their own purpose. Its popularity resulted from both its spectacular form and operatic repertoire drawing inspiration from great epics in the history of China. Love stories, fights and legends have always been and are the most popular topic in Chinese opera (Capdeville-Zeng, 2009, pp. 172-173).

Magazines also paid a lot of attention to shadow puppet theatre. "As" [Ace] emphasized that Chinese shadow puppet theatre - "Yin-Czi" or "Yu-Ko-Sze" (Yin Chi or Yu-Kou-She) was one of the oldest arts and an external indicator of ancient civilization. Due to shadow puppet theatre both reflecting beliefs related with philosophical and religious systems of the Middle Kingdom and being able to create illusions and leave a lasting impression, it enjoyed great popularity among the Chinese people. Furthermore, it was a serious competition for actors. Nanjing, Hankou, Guangzhou (Turski, 1937, p. 15), Beijing were cities where most performances were staged. "Teatr w Szkole” [Theatre at school] mentioned that although shadow play enjoyed massive popularity among Indians, Persians, Japanese, Malaysians and Javanese, 
China (Giliński, 1936, pp. 49-51) was the motherland of shadow puppet theatre. Just the preparation of performance was a separate art. "As" [Ace] also paid attention to proper portrait (figures) making, light setting and choosing an appropriate repertoire. According to "As" [Ace], stimulating creativity of a child, encouraging them to broaden their knowledge about the world especially about history, geography and nature (Giliński, 1936-1937, pp. 85-87) were the biggest advantages of staging shadow plays. It can be considered as an interesting tidbit of information that shadow puppetry theatre has been known in China since the reign of Western Han dynasty (206 BC - 9 AD) (Mackerras, 2009, p. 986). Chinese shadow puppet theatre is still enjoying considerable popularity; singing and dancing also play an important part and the rules to which a performance adheres, are analogous to the rules that Beijing Opera adhere to (Kajdański, 2009, pp. 273-274).

The Polish press in the 1930s also directed its attention to Japanese theatre. "Na Szerokim Świecie" [Worldwide] explained that Japanese theatre was extremely different from gentle, sensitive court poetry because it was characterized by sudden gestures, expressive sometimes monstrous or grotesque masks and brutal and detailed scenes (Dwie twarze, 1936, p. 9). According to "Antena" [Antenna], due to Japanese theatre having a fairy tale quality, it enjoyed immense popularity among all inhabitants of the Land of Rising Sun. Fukurukuju (Felsztyński, 1935, p. 5) - the god of love, wisdom and wealth was the patron god of Japanese theatre. It should be clarified that traditional Japanese theatre includes nō, kyōgen, ningyō jōruri, kabuki. The Polish press did not always mention that when it described Japanese theatre. Modern Japanese theatre was said to be in its prime at the beginning of the 17 th century. At that time ningyo joruri- puppet theatre was created which in the 19th century became known as bunraku and kabuki- bourgeois theatre. No theatre popular in the Middle Ages remained the art of aristocracy and samurais (Melanowicz, 2012, p. 230).

Illustrated magazines spoke favourably of Japanese theatre. „Bluszcz” [Ivy] emphasized that $n \bar{o}$ theatre was the oldest Japanese theatre and originated from Shinto mystery plays. It was in full bloom as a court art during the shogunate in the 14th century (Lubańska, 1938, p. 10). It was characterized by original costumes and lack of realism which helped to depict a beautiful, undisturbed and unreal world (Lubańska, 1938, p. 13). 
"Antena" [Antenna] stressed that Japanese theatre was perfectly constructed, and it did not contain any unnecessary elements. Furthermore, it was characterized by performance at the highest standard, appropriate colours, authenticity. An exaggeration of certain elements such as the fight between good and evil in some plays was considered to be its shortcoming. It may have been the product of Japanese theatre seeking to raise the nation's spirits, interest the audience in a particular topic and properly represent religious symbolism (Felsztyński, 1935, p. 5). Janina Lubańska, the correspondent of "Tęcza" [Rainbow] and "As" [Ace], who saw a play performed at nō theatre, was enchanted with the play even though she stressed that the play lasted six hours, she did not understand the lines actors delivered and she had to sit in a traditional position which she found very uncomfortable. She commended actors' costumes which enchanted her with its wealth of colours and a perfect combination of sometimes contrasting colours (Lubańska, 1938, p. 11).

Both "Antena” [Antenna], "As” [Ace], "Bluszcz” [Ivy], "Na Szerokim Świecie" [Worldwide], "Tęcza” [Rainbow] and "Z Bliska i z Daleka” [From Near and Far] emphasized that there were considerable differences between Japanese and European theatres even though they sought some similarities. "As" [Ace] mentioned that the Shakespearean theatre (Stypuła, 1938, p. 5) was the European equivalent of kabuki. The magazine added that a European would not understand Japanese theatre whereas a Japanese would be charmed by a play (P.W., 1938, p. 15). On the other hand, "Na Szerokim Swiecie" [Worldwide] explained that Japanese theatre was a combination of dance, song and theatre and opera would be its European equivalent (Liński, 1938, p. 4). „Bluszcz” [Ivy] while describing Japanese theatre nō mentioned that „the play is visually and aurally so weird, so Eastern and ancient, so inexplicably difficult to describe. No such thing has been seen or heard in Europe. Every performance of nō is a dreamed fairy tale, a tragic Japanese tale” (Lubańska, 1938, p. 13). However, „Bluszcz” [Ivy] also noted that because of choir performance, use of masks, only men being able to perform in Japanese theatre can be compared to classical Greek theatre (Lubańska, 1938, p. 11).

Magazines tried to enumerate differences between Japanese theatre and Japanese theatre, but they did not always explain their origins. "Z Bliska i z Daleka" [From Near and Far] noted that performances usually started at 
4 p.m. and ended at 8 p.m. However, the magazine did clarify that drama, comedy, and romantic stories lasted two hours. Another difference was that all male and female parts were played by men. Furthermore, a singer who sang with a throaty assumed the role of narrator and explained the plot sadly accompanied by the lute and drum (Klein, 1936, p. 85). On the other hand, Janina Lubańska mentioned in „Bluszcz” [Ivy] that performance she watched started at 4 p.m. and it ended at 10 p.m. and drum and flute (Lubańska, 1938 , p. 12-13) were the only instruments she heard at the performance. "As” [Ace] “Z Bliska i z Daleka” [From Near and Far] and „Bluszcz” [Ivy] also mentioned that national dramas or legend were most often staged, and the performance could last even ten hours (P.W., 1938, p. 15). It is worth emphasizing that a play in kabuki theatre is composed of several acts each of which is a separate story. As a result, a performance lasted many hours. Therefore, the audience had meals, smoked and chatted in order to distract itself. (Niedbalska-Asano, Asano, 2012, p. 96).

The interior of Japanese theatre was different from European theatre in some aspects. "As" [Ace] made an observation that the kabuki stage features a walkway called a "flower path" extending to the audience on which walked the actors in order to be in a better contact with the audience (Lubańska, 1938, p. 15; Stypuła, 1938 p. 4). The magazine summed up that „Japanese show centuries-old tradition of stage technique. Almost every construction invention such as a moveable stage etc which were introduced to us in the last century had been well-known to the Japanese for many centuries" (Stypuła, 1938, p. 4). On the other hand, Janina Lubańska in „Bluszcz” [Ivy] describing the décor of nō theatre noted that the stage was modelled after European stage and boxes were built in Japanese style. Furthermore, the stage which had been polished like a mirror contributed to an incredible impression as the silhouettes of performers were clearly reflected on the stage's surface. Honorary boxes facing south were an additional innovation (Lubańska, 1938, p. 13).

The press highlights that the walkway hashigakari where actors walk between the stage and dressing rooms, plays an important part in $n \bar{o}$ theatre. In the no theater, the movement of an actor from a town (michiyuki) on a small $n \bar{o}$ stage can be signaled in several ways. One of them is the passage along the hashigakari, which can symbolize, for example, a vestibule or a boat, and the 
main scene (hon butai), is the proper destination (Żeromska, 2010, Vol. 1, p. 289). Whereas in kabuki theatre the walkway hanamichi ["flower path"] that makes it possible for artists to move around the stage is important part of the stage. Moreover, moveable scenes invented by the playwright Namiki Shōzō (1730-1773) in the 18th century, trapdoors and stage barrels contributed to performances being considered as a marvel (Niedbalska-Asano, Asano, 2012, pp. 96, 153; Melanowicz, 2012, pp. 168, 232).

Magazines focused on a different acting style. "Na Szerokim Świecie" [Worldwide] claimed that Europeans thought that Japanese acting was exaggerated. However, such acting was natural for Japanese people as it indicated the protagonist of a particular play. Nonetheless, the magazine criticized exaggeration in acting because it turned every Japanese drama and comedy into melodrama and farce respectively (Dwie twarze, 1936, p. 9). "Z Bliska i z Daleka" [From Near and Far] told an anecdote which was to illustrate this cultural difference. Józef Scherer, who had been living in Japan for some time, said that if it had not been for his Japanese friend's help, he would not have been able to tell the difference between comedy and drama. As he explained, Japanese people laughed wholeheartedly as well as burst out crying (Klein, 1936, p. 85) while watching comedy and drama.

It is a high possibility, that Józef Scherer saw a spectacle which contain both tragedy $(n \bar{o})$ and comedy (kyōgen) parts. It should be emphasized here how nō differs from kyoggen. The first is art, tragedy, and the second is a farce. As Estera Żeromska emphasizes, $n \bar{o}$ and kyōgen emerged at a similar time from similar sources and for several hundred years they have been exhibited alternately on the same stage as part of one performance. They complement each other, because in both cases the most important thing is the truth about man. No perceives the truth about him in a tragic way, and kyoggen - comic (Żeromska, 2010, Vol. 1, p. 227).

Józef Scherer pointed that the Japanese audience's behaviour was exaggerated, because Japanese tragedy was differed from Polish. It is not altogether truth. Beata Kubiak Ho Chi points out the similarities between Japanese and Polish tragedy on the example of two eighteenth-century works: "Kokusen'ya kassen" [Battle of Coxinga] written by Monzaemon Chikamatsu (real name Suginomori Nobumori, 1653-1724) and "Tragedy of Epaminondas” written by Polish playwright Stanisław Konarski [1700-1773]. In both cases, the 
source of the tragedy was the necessity of sacrificing oneself for the greater good, the inevitability of destiny, as well as the subject matter related to the state and the nation. In both cases, the works were supposed to condemn evil deeds and praise good ones, cause catharsis in the viewer, as well as encourage him to undertake heroic deeds. However, Japanese artists put a stronger emphasis on the fact that with the help of sublime lyrics and music, strong emotions in the audience (Beata Kubiak Ho-Chi, pp. 206-208).

"Antena" [Antenna] made it clear that Japanese acting style cannot be judged according to European criteria. Magazine explained that an actor was required to be a good acrobat and gymnast as those skills turned out quite often to be indispensable in playing the part. Their enunciation was particular and to foreign listeners it may have seemed to be throaty (Felsztyński, 1935, p. 5). Janina Lubańska commented in "Bluszcz" [Ivy] that despite not speaking the language an European would be able to understand Japanese performance thanks to clear gesture code (Lubańska, 1938, pp. 12-13). Moreover due to clear gesture code a European could appreciate more performance's value. She described that "not speaking the language gives him an advantage of being able to absorb most important artistic qualities of „nō” drama and it was possible to become immersed in undisturbed observation of actors' intriguing movements, their robes, mask expressions, low choir chanting and pure oriental music- one of its kind without following the meaning of „utai” phrase" (Lubańska, 1938, p. 13). "As" [Ace] claimed that Kumaju Hangoro, one of the most famous actors, enjoyed working with a mask (Dobrowolski, 1936, pp. 21-22). Magazine printed on its titular page the picture of Kikugorō Onoye VI (real name Terashima Kōzō, 1885-1949), kabuki actor, with singer Feodor Chaliapin (1873-1938) (Strona tytułowa, 1936, p. 3).

Press also commented on the proper education of Japanese actors. "Tęcza” [Rainbow] informed that contrary to European actors, Japanese artists had been preparing for their profession since childhood, they created a caste and dynasties of actors kept their secrets. On one hand their roles were perfected in every single detail, but on the other hand their acting was run-of-the-mill, stereotypical and focused too much on presenting the acting style of their clan (Szt., 1932, pp. 17-18). „Bluszcz” [Ivy] informed that actors not only inherited particular roles but also masks which were treated as a most precious heirloom that had been in their clan for many generations (Lubańska, 1938, 
p. 12). "Na Szerokim Świecie" [Worldwide] stressed that in Japanese theatrical troupe Takarazuka also performed alumnae of Theatrical Academy. The magazine also added that studies took seven years and education level of girls who studied there rivalled university education. Apart from mastering the acting art and broadening their knowledge of theatre, women also plumbed the mysteries of music, singing and European and Japanese dances (Liński, 1938, pp. 4-5).

It should be borne in mind that nō theatre includes the elements of sacral, court dances and dances in masks. Moreover, it derives many elements from the sarugaku art which combines dance, songs, acrobatics and comic scenes. Nonetheless, an outsider unfamiliar with Japanese art may find Japanese theater performance slow and the plot may be considered to be lackluster. Jadwiga Rodowicz-Czechowska, calls the movement in the no theater „the figure of the lost, the filling of emptiness". The performance technique in this theater is to compensate for the loss. The main character always talks about the loss that he thinks should be filled. Filling up, however, is accomplished not with words, but with an excess of gestures. The actor repeats the same movements and gestures to fill the aforementioned emptiness. (Rodowicz-Czechowska, 2020, pp. 200-201). Kataoka Hidetarō (ur. 1941), one of the most famous kabuki actors, emphasizes that the basic feature of $n \bar{o}$, kyōgen, jöruri (bunraku), is: a stylized way of expression, attachment of great importance to form, as well as the creation of an appropriate atmosphere showing different emotions. One of the actors' tools are fixed executioner gestures. In kabuki, the actor has a much richer repertoire, and his gestures are characterized by greater simplicity and realism. Kabuki theatre is set in the convention of psychological realism. On the other hand, in kabuki, male roles are played by male actors (onna-gata). In order to create illusions of femininity, they must often use excessively expressive means of communication (Żeromska, 2012, Vol. 2, pp. 174-175). Kawatake Toshio (1923-2013), a researcher of traditional Japanese theater, emphasized that in kabuki the position and role of the actor are crucial and basic, because it is he who invents the way of playing most adequate to the situation prevailing at the moment. That is why he called kabuki theatre actor-centered", in contrast to (word--centered) western theatre (Rutkowska, 2015, p. 91). Gunji Masakatsu added that in kabuki the text is only a sketch, not a ready-made project, and 
the most important goal of kabuki is not to convey the content of the text, but to show the event itself in such a way as to meet the expectations of the audience (Rutkowska, 2015, p. 91).

As a curiosity, it can be said that initially only women played kabuki. The date of the creation of kabuki is considered to be the year 1603, when the priestesses of Okuni first presented their dances in Kyoto. However, already in 1629 , women were forbidden to perform in the theater and women's roles began to be played by men. Although the aforementioned ban was lifted in the second half of the nineteenth century, the profession of onna-gata persisted. It is worth emphasizing that in kabuki theatre actors are the most important whereas script merely provides them with hints. The artist has to properly emphasize scenes meant to be dramatic using gestures, poses and declamation (Żeromska, 2012, Vol. 2, pp. 174-175; Varley, 2006, pp. 113 and 184-186; Melanowicz, 2012, s. 169-170).

The Polish press paid a lot of attention to traditional Japanese masks. In "Bluszcz" [Ivy], Janina Lubańska called them a masterpiece which perfectly reflected the character's emotions. Thanks to this, masks were an outstanding feature of nō theatre as they liberated the actor from make-up and their workmanship and expressions were superior to masks used in Ancient Greek theatre. The journalist added that there was a specialist classification and only protagonists wore masks (Lubańska, 1938, p. 11). “Tęcza” [Rainbow] shared the same idea as the magazine not only claimed that grotesque masks and an appropriate make-up played an important role, but also gave some examples and explanations of their meaning stressing at the same time that thanks to an appropriate make-up a youngster could play the part of an elderly man. Matsumoto Kōshirō (1870-1949) (Szt., 1932, pp. 17-18) was an especially meritorious master of mask making in Tokyo. However, the journal did not avoid a fundamental error and did not differ in the genres of Japanese theater. Masks are characteristic only for $n \bar{o}$ and kyōgen and makeup only for kabuki. The history of Japanese theater masks has its origin in the belief that the soul of a man who died a tragic death can take revenge. Only the honor of the deceased did the danger end. The first mask, from a mollified spirit, was to be given to semi -legendary Hata-no Kawakatsu (VI century), the founder of Konparu - one of the first schools nō. It was supposed to scare away unfavorable spirits. To this day in the nō theater, 
the roles are played by the demonic mask onryō (angry spirit) and kishin (demon-beast), and the face of Old Man Okina, symbolizing a soul that has already experienced solace in the afterlife. (Rodowicz-Czechowska, 2020, pp. 197-200). "Na Szerokim Świecie" [Worldwide] also put an emphasis on masks playing a special role in Japanese theatre as it replaced make-up and actor's facial expressions. It also added that the art of making a mask was one of the most sophisticated and subtle in the world (Dwie twarze, 1936, p. 9). Again, the press did not differ in the genres of Japanese theater. It is true that in no theatre decorations and props are simple and have an already established meaning. Masks play a special part as they describe the type of character played and reflect their emotions. Janina Lubańska had a point in claiming that only protagonists wore masks. Whereas "Tęcza" [Rainbow] mentioned that make-up (kumadori) and pose (mie) played a special part in kabuki theatre. (Niedbalska-Asano, Asano, 2012, pp. 93 and 153).

"Na Szerokim Świecie" [Worldwide] and "As" [Ace] reported about the performance of Japanese group Takarazuka. Here it should be explained that Takarazuka Musical Theatre based in Takarazuka was the first revue theatre in Japan founded by Kobayashi Ichizo (1873-1957). It had its first performance in 1914 whereas its first overseas tour took place in 1938. Contrary to traditional Japanese theatre, Takarazuka to this day is all-female theatre (Niedbalska - Asano, Asano, 2012, pp. 210-211). Henryk Lisiński, the correspondent of "Na Szerokim Świecie" [Worldwide], who saw the Takarazuka performance emphasized that their first performance in the National Theatre in Warsaw had been recently one of most ceremonial premieres. Appraising the performance he was enchanted with ingenuity and harmonious colour scheme of decorations and actresses' costumes. He also marvelled at presented dances, especially ritual "summer" dance, the dance of samurais with swords and the lion dance. He added that the play" The knight and the demon in the mountains" was staged with austerity and beauty in accordance with bushido rules. The audience was reported to be greatly impressed by the play (Liński, 1938, pp. 4-5). “As" [Ace] commented in a similar vein that the premiere of Takarazuka enjoyed widespread popularity. He emphasized at the same time that "Japanese actresses similar to "petite figurines" wearing florid kimonos appeared on the scene like a swarm of butterflies". He mentioned actresses: Kumono Kuyoke and Maki Fuji. He 
praised that although the Japanese theatre looked from the backstage like a camp, everything was well-organized and everyone carried out their duties (Stypuła, 1938, pp. 4-5 i 7).

"As" [Ace] also mentioned Japanese puppet theatre. It stressed that puppet plays in Japan were as popular as traditional plays. Puppet theatre, especially bunraku in Osaka, gained immense popularity and "Chūshingura" a story of 47 rōnin was their greatest play (Ten, 1936, p. 28). It should be noted here that the term bunraku, is the name of the only professional puppet theater in Osaka, and not synonymous with Japanese puppet theater (ningyo jöruri). Estera Żeromska emphasizes that bunraku consists of three components: words, music and puppets. Each of them grew from a different source and developed independently. Only when combined together do they form a coherent performance. The artist must be aware that he is only an element of a harmonious whole and is also responsible for its coherence. (Żeromska, 2010, Vol.2, p. 233). The first depictions with the use of dolls were a form of sacrifice and prayers to the deities. The beginning of secular puppet theater can be considered the Heian period (794-1185), which was initiated by Chinese puppeteers settled in Japan. Its peak dates back to the 14th century when puppets animated by strings were imported to Japan from China. Furthermore, puppet theater had been greatly inspired by kabuki theatrical forms since the end of the 16th century. Sometimes dolls also replaced actors in the plays nō and kyoggen. The special genre of Japanese puppet theater is bunraku. The bunraku plays were usually divided into historical dramas (jidaimono), dramas of manners and social dramas (sewamono) and the most famous playwright was Chikamatsu Monzaemon. Those performances enjoyed big popularity because of interesting text and fantastic acrobatics and supernatural feats performed by puppets (Żeromska, 2010, Vol. 2., pp. 234-237; Varley, 2006, pp. 187-188; Melanowicz, 212, p. 232).

Beata Kubiak - Ho Chi draws attention to the fact that the concept of "tragedy" appeared in Japan only in the second half of the nineteenth century and was initially perceived as a genre of drama. At that time, the plays of Chikamatsu Monzaemon were again popular. That is why usually adaptations of his works for the needs of puppet theater were called: "tragedies" instead of "dramas" (Kubiak-Ho Chi, 2012, p. 202). 
Both "Antena" [Antenna] and "As" [Ace] stressed that Japanese theatre enjoyed immense popularity (Ten, 1936, p. 28; Felsztyński, 1935, p. 5)."Bluszcz" [Ivy] on the other hand had a different opinion. Janina Lubańska, based on personal experience, declared that currently Japanese nō theatre enjoys very little popularity among the Japanese and became aristocracy's snobbish entertainment (Lubańska, 1938, p. 10). “Tęcza” [Rainbow] lamented that currently Japanese theatre was losing competition with cinema "bending under its assault like a branch of alder tree tormented by gusts of wind". The magazine reasoned that both image, graphic arts, painting and visual effects were much more important in Japan than anywhere else. Furthermore, it was in Japan where more monumental movies had been recently produced than in many European countries (Szt., 1932, pp. 17-18).

Journalists who described Oriental theatres are usually based on personal experience. It was the case of correspondents of "Teatr" [Theatre] - Edward Kuryło, "Tęcza” [Rainbow] - Magdalena Lipkowska, "As" [Ace] and "Bluszcz" [Ivy] - Janina Lubańska, "Na Szerokim Świecie” [Worldwide] - Henryk Liński and "As" [Ace] - Wojciech Stanisław Stypuła. Thanks to this they were able to describe accurately and correctly their nuances as well as added interesting tidbits of information.

Both specialist, mass and popular press paid particular attention to elements that distinguished Japanese and Chinese theatre from their European counterparts. The length of performance, innovative technical solutions, different acting style were the elements that received most attention. Nonetheless, sometimes it was impossible to explain the origins of those differences.

Furthermore, the above-mentioned differences usually spoke against Chinese theatre. It was criticized for different music, moveable stage scenery, exaggerated acting that was hard to understand. Such an attitude was the result of lack of understanding of opera's conventions. On the other hand, the press eagerly commended the richness of actors' costumes and shadow puppet theatre. Moreover, the Polish press also stressed that both classical and modern Chinese theatre enjoyed immense popularity among Chinese people.

The Polish press went easy on theatrical art in Japan depicting differences that were in many cases the same as in Chinese theatre as something neutral, even positive as it gave the play magical touch. Sometimes it was emphasized that Japanese theatre could become a source of inspiration for its European 
counterpart. It was praised for masks, costumes, moveable stage scenery and music. It is interesting that in the last two instances Chinese theatre was looked down on. The Polish press also spoke favourably of puppet theatre and Takarazuka performances. On the other hand, magazines' opinions on acting varied. Furthermore, they also debated whether the European audience will be enchanted by the performance. They also had different opinions on traditional Japanese theatre enjoying widespread popularity among Japanese people.

Although the journalists writing about traditional Chinese theatre were usually well-prepared, they still could not avoid making mistakes. Unfortunately, their knowledge about traditional Japanese theatre was poor and based on the cliches. The Schoolboy's error was not stating clearly in their articles whether they had in mind kabuki or nō. Nonetheless, the information contained in those articles could often, especially in the case of Japanese theatre's description, positively influence the knowledge of the citizens of the Second Polish Republic about this subject.

\section{MGR KATARZYNA MICHALEWICZ}

Instytut Historyczny

Wydział Nauk Historycznych i Pedagogicznych

Uniwersytet Wrocławski

ul. Szewska 48, 50-139 Wrocław

katarzyna.michalewicz@poczta.onet.pl

\section{Bibliography}

Sources:

„Antena” [Antenna] [1934-1939]

„As” [Ace] [1935-1939]

„Bluszcz” [Ivy] [1931-1939]

„Na Szerokim Świecie” [Worldwide] [1931-1939]

„Teatr” [Theatre] [1931-1939]

„Teatr w Szkole” [Theatre at school] [1934-1939]

„Tęcza” [Rainbow] [1931-1939]

„Z Bliska i z Daleka” [From Near and Far] [1933-1939]

„Życie Sztuki” [Life of Art] [1934-1939] 


\section{Articles:}

(1931, 5 lipca). Wzdłuż Chińskiego muru, Na Szerokim Świecie, nr 27, p. 9.

(1931, 31 października). Carmen chińska, Bluszcz, nr 44, p. 15.

(1936, 18 października). Dwie twarze żółtych ludzi, Na Szerokim Świecie, nr 42, p. 9.

(1936, 8 marca). Strona tytułowa, As, nr 10, p. 3.

(1938, 2 stycznia). Chińskie maski. Na Szerokim Świecie, nr 1, p. 9.

Dobrowolski, Wł.J. (1936, 9 sierpnia). Twarz i maska, As, nr 32, pp. 21-22.

Felsztyński, S. (1935, 19 maja). Teatr Japoński, Antena, nr 20, p. 5.

Giliński, M. (1936, listopad). Teatr chińskich cieni, Teatr w Szkole, nr 3, pp. 49-51.

Giliński, M. (1936-1937, grudzień - styczeń). Teatr chińskich cieni - (dokończenie), Teatr $w$ Szkole, nr 4, pp. 85-87.

Hovo-Joei, Y. (1939). Życie Sztuki za granicą - Chiny, Życie Sztuki, R.4, pp. 256-258.

Klein, K. (1936, marzec). Jak to było w Japonii, Z Bliska i z Daleka, nr 31, pp. 85-86.

Kuryło, E. (1931, czerwiec - sierpień). Teatr chiński. Teatr, nr 10, pp.192-194.

Liński, H. (1938, 11 grudnia). Takarazuka, Na Szerokim Świecie, nr 50, pp. 4-5.

Lipkowska, M. (1937, sierpień). China Town. Tęcza, nr 8, pp. 55-56.

Lubańska, J. (1938, 10 lipca). Maiko - kwiaty spod Fudżijamy, As, nr 28, pp. 15-16

Lubańska, J. (1938, 2 lipca). Japoński teatr dramatyczny „No”, Bluszcz, nr 27, pp. 10-12.

Lubańska, J. (1938, 9 lipca). Japoński teatr dramatyczny „No”, Bluszcz, nr 28, pp. 13-15.

P.W. (1938, 8 maja). Japonja a la Fourchette, As, nr 19, p. 15-16.

Stypuła, W.S. (1938, 11 grudnia). Takarazuka - w masce i bez maski, As, nr 50, pp. 4-5 i 7.

Szt., Z. (1932, lipiec). Aktorzy japońscy, Tęcza, nr 7, pp. 17-18.

Ten. (1936, 6 grudnia). Zabawki Małej Kikuko, As, nr 49, pp. 28-29.

Turski, M. (1937, 25 lipca). Chiński teatr cieni, As, nr 30, p. 15.

\section{Literature on the subject:}

Capdeville-Zeng, C. (2009). Opera. W: T. Sanjuan (red.), Leksykon Wiedzy o Chinach współczesnych (172-173). Warszawa: Wydawnictwo Akademickie Dialog.

Kajdański, E. (2005). Chiny Leksykon. Warszawa: Książka i Wiedza.

Kasarełło, L. (1995). Tian Han. U źródeł teatru chińskiego. Warszawa: Wydawnictwo Akademickie Dialog.

Kolb, C. (2009). Han Dynasty. W: L. Cheng, K. Brown (red.), Encycopedia of China Volume 2 (985-990). Massachusetts: Berkshire.

Kubiak Ho Chi, B. (2012). The tragic in Japanese and Polish 18th -century Drama: The battles of Coxinga by Chikamatsu and The Tragedy of Epaminondas by Konarski. W: K. Wilkoszewska (red.), Aesthetics and Cultures (199-208). Kraków. Wydawnictwo Uniwersyteckie Universitias.

Künstler, J. (2019). Dzieje kultury chińskiej. Warszawa: PWN.

Łabędzka, I. (1999). Obrzędowy teatr Dalekiego Wschodu. Poznań: Wydawnictwo Naukowe UAM.

Mackerras, C. (2009). Opera Beijing. W: L. Cheng, K. Brown (red.), Encycopedia of China Volume 4 (1652-1654). Massachusetts: Berkshire.

Mackerras, C. (2009). Opera, Regional. W: L. Cheng, K. Brown (red.), Encycopedia of China Volume 4 (1655-1659). Massachusetts: Berkshire.

Melanowicz, M. (2012). Historia literatury japońskiej. Warszawa: PWN. 
Niedbalska-Asano, P., Asano M. (2012). Japonia leksykon. Warszawa: Książka i Wiedza.

Osiński, Z. (2008). Polskie kontakty teatralne z Orientem w XX wieku, studia. Gdańsk: Słowo/ Obraz Terytoria.

Paczkowski, A. (1980). Prasa Polska 1918-1939. Warszawa: PWN.

Rodowicz-Czechowska, J. (2020). Inne Nō. Kraków: Muzeum Sztuki i Techniki Japońskiej Manggha.

Rutkowska, I. (2015). Boska obecność. O względności tekstu i rytuału w teatrze kabuki. Krakow: Universitias.

Varley P. (2006). Kultura japońska. Kraków: Wydawnictwo Uniwersytetu Jagiellońskiego. Żeromska, E. (2010). Japoński teatr klasyczny. Korzenie i metamorfozy. Tom 1. Nō, kyōgen. Warszawa: Wydawnictwo Trio.

Żeromska, E. (2010). Japoński teatr klasyczny. Korzenie i metamorfozy. Tom 2. Kabuki, bunraku. Warszawa: Wydawnictwo Trio. 